F. Pepe $\cdot$ A. Sulli $\cdot$ M. Agate $\cdot$ D. Di Maio $\cdot$ A. Kok

C. Lo Iacono $\cdot$ R. Catalano

\title{
Plio-Pleistocene geological evolution of the northern Sicily continental margin (southern Tyrrhenian Sea): new insights from high-resolution, multi-electrode sparker profiles
}

Received: 17 March 2003/ Accepted: 12 May 2003/Published online: 8 July 2003

(C) Springer-Verlag 2003

\begin{abstract}
High-resolution seismic profiles were acquired in the north Sicily offshore region with an innovative, multi-tip sparker array which lacks ringing and has a base frequency around $600 \mathrm{~Hz}$. The new data, combined with published data, suggest that intra-slope and extensional basins formed as a consequence of the late Miocene (?)-early Pliocene shortening and thrusting, and the middle (?)-late Pliocene continental rifting affecting the internal side of the Sicilian-Maghrebian chain. Early (?) Pleistocene to Holocene high-amplitude and high-frequency sea-level changes resulted in repeated sub-aerial exposure and flooding of the shelf, and the deposition of cyclically arranged hemipelagic and shelf sediments. An uplift of the shelf could explain the non-preservation of the transgressive and of the lowstand wedge systems tracts in the oldest sequences.
\end{abstract}

\section{Introduction}

The continental margin off northern Sicily (CNS) is late Neogene to Recent in age, having developed along the southern border of the Tyrrhenian Sea where it is partly superimposed on the Sicilian-Maghrebian chain (SMC, Fig. 1). The SMC is unconformably overlain by Upper Neogene to Recent deposits which formed in shallow- to deep-water environments and consist of evaporitic, hemipelagite, terrigenous, and volcanoclastic sediments (Bacini Sedimentari 1980). The thickness and sedimen-

\footnotetext{
F. Pepe $(\bowtie) \cdot$ A. Sulli $\cdot$ M. Agate $\cdot$ D. Di Maio $\cdot$ C. Lo Iacono R. Catalano Department of Geology and Geodesy, Palermo University, 90123 Palermo, Italy E-mail: fapepe@unipa.it

Tel.: + 39-91-6230310

Fax: + 39-91-6230314

A. Kok

Geo-Resources Consulting B.V., 3023 CD Rotterdam, The Netherlands
}

tology of these coeval deposits are extremely variable and are controlled not only by the tectonics but also by high-amplitude $(>100 \mathrm{~m})$ sea-level changes and associated sedimentary regimes.

During the last few decades, geophysical and geological surveys have produced a large dataset in the CNS. A literature review (Bacini Sedimentari 1980; Wezel et al. 1981; Fabbri et al. 1981; Barone et al. 1982; Lucido 1992; Agate et al. 1993; Agate and Lucido 1995; Pepe et al. 2000) indicates that the seismic characteristics of these profiles are particularly suitable for tectonic studies at basin to margin scales, but raise several questions concerning higher-resolution scales (e.g. the Plio-Pleistocene sequence stratigraphy). To fill this data gap, a survey (cruise Sicily 2001) was conducted in the period 1-13 August 2001. The objectives of the cruise were (1) to test newly designed, multi-tip sparker arrays for the generation of acoustic pulses; (2) to detail the seismic stratigraphy of the Quaternary deposits formed on the northern Sicily shelf; and (3) to describe the Plio-Pleistocene sedimentary infill of the deep basins developed north of this area in finer detail.

This paper focuses on a detailed description of some of the seismic profiles. The new data and their interpretation were then combined with published data to provide new insights into the Plio-Pleistocene tectonic and sedimentary evolution of the study area.

\section{Geological setting}

Seafloor topography and physiographic features

The north Sicily continental margin extends from the coastline of north Sicily to the Marsili Abyssal Plain. From south to north, a continental shelf, continental slope, and continental rise can be recognised. The shelf is generally less then $8 \mathrm{~km}$ wide, with an average gradient of $\sim 1.5^{\circ}$. The depth of the shelf margin ranges from $\sim 90$ to $\sim 135 \mathrm{~m}$ (Wezel et al. 1981; Agate et al. 1998). The continental slope can be divided into an upper and a 


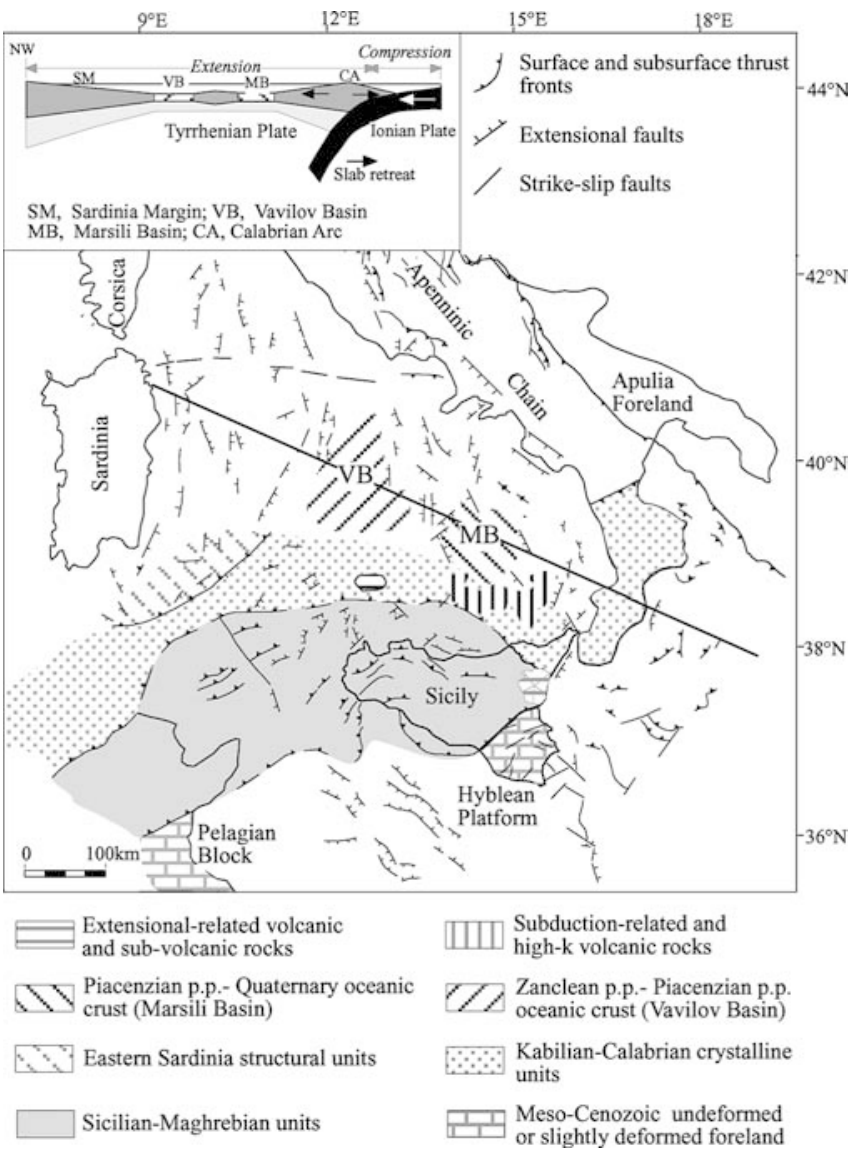

Fig. 1 Structural sketch of the Tyrrhenian Sea and Apennines simplified from Bigi et al. (1983), and Catalano et al. (1996). Inset Schematic section across the Tyrrhenian area

lower slope with a high gradient, separated by flat areas $\sim 1,500 \mathrm{~m}$ deep. The lower continental slope reaches a depth of $\sim 3,000 \mathrm{~m}$ at the continental rise. The morphology of the continental slope is irregular due to the presence of structural highs, landslide areas, and canyons (Fig. 2). On the basis of the bathymetric profiles, the CNS is considered to be a typically immature continental margin (Wezel et al. 1981).
The Cefalù Basin is thought to be a major extensional basin developed in the central sector of the margin (Bacini Sedimentari 1980; Fabbri et al. 1981; Barone et al. 1982; Pepe et al. 2000). The upper slope and structural highs (e.g. Solunto High) or volcanic edifices (Aeolian Arc) border this basin (Fig. 2). The volcanic activity began in the Pliocene and is locally still ongoing today, being characterised by calc-alkaline magmatism as well as explosive events (Barberi et al. 1974).

\section{Previous studies}

From top to bottom, the SMC consists of a southeast vergent, $12-15 \mathrm{~km}$ thick, middle (?) to late Miocene tectonic stack formed by (1) pelagic to terrigenous (Sicilide) and Miocene flysch-type nappes; (2) nappes of Mesozoic-Paleogene basinal carbonates, and (3) thick imbricates of Meso-Cenozoic platform carbonate rock (Catalano et al. 1985; Beccaluva et al. 1986; Catalano et al. 1996).

NW-SE- to E-W-trending normal faults of late (?) Miocene age have partially dissected the tectonic wedge to form extensional basins (e.g. Cefalù Basin). These basins were subsequently filled by clastic to evaporitic deposits of variable thickness and internal geometries (Bacini Sedimentari 1980; Fabbri et al. 1981; Barone et al. 1982).

Submerged structural highs, mainly composed of Mesozoic-Cenozoic carbonates with a terrigenous cover, formed as consequence of the late Miocene (?)-early Pliocene thrusting of the SMC (Fig. 3). The topographical lows have subsequently been filled with Plio-Pleistocene clastic and pelagic sediments (Catalano et al. 2002). Small-scale thrusting in the pre-Middle (?) Pliocene sediments of the Cefalù Basin as well as towards the north formed during this time interval (Pepe et al. 2000).

Generalised stretching affected large parts of the margin during the middle (?)-late Pliocene. Extension caused widespread normal faulting (Bacini Sedimentari 1980; Fabbri et al. 1981; Barone et al. 1982) and crustal
Fig. 2 Seafloor topography and physiographic features of the CNS. MAB Marsili Abyssal Plain, $C R$ continental rise, $A A$ Aeolian Arc, $S H$ Solunto high, $S V C$ San Vito Canyon, $C B$ Cefalù Basin, US upper slope, $P G$ Palermo Gulf, TG Termini Gulf, $P A G$ Patti Gulf. Water depth contours are in metres. $A-A^{\prime}$ Location of Fig. 3

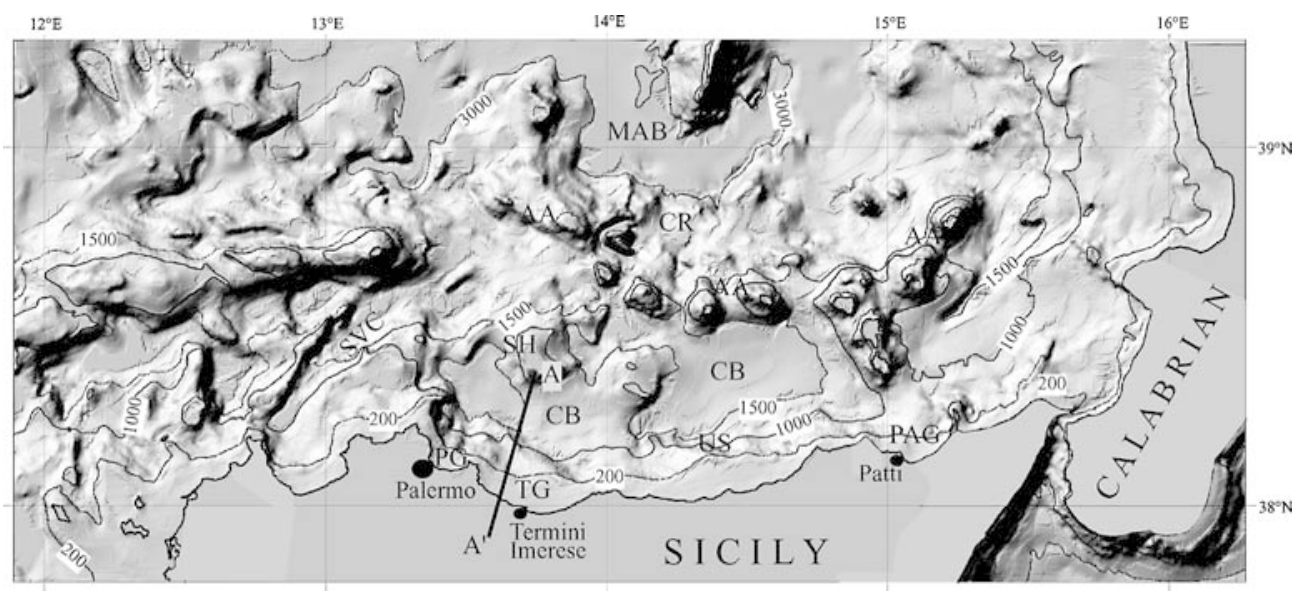


Fig. 3 Structural cross section across the central-southern CNS and its adjacent onshore area, based on high-penetration seismic reflection and field data (simplified from Catalano et al. 2002). Location in Fig. 2

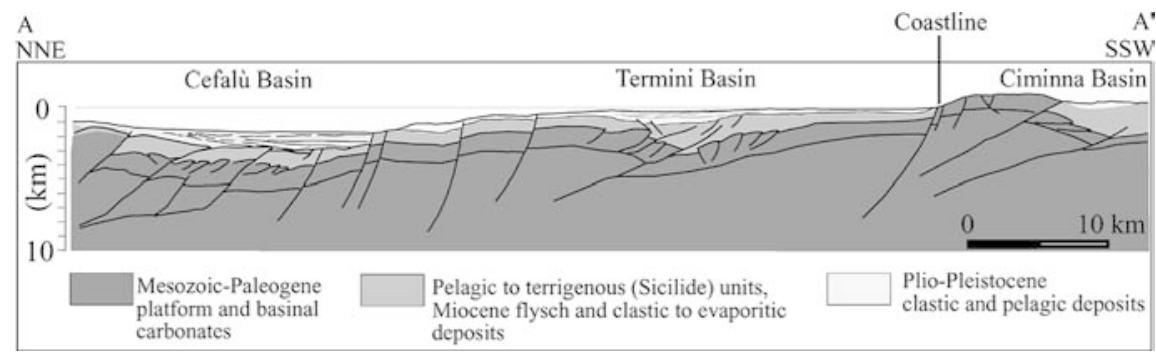

thinning (Pepe et al. 2000). In Pleistocene (?) times, the extension ended in the Cefalù Basin and further to the north (Pepe et al. 2000). A continuation of the extension is indicated towards the south where E-W- to NE-SWtrending normal faults are quite common and exert a control on the morphology of the coastal areas. Minor strike-slip structures are recognised in the offshore of the Nebrodi-Peloritani chain (Nigro and Sulli 1995), and between the Cefalù and Ciminna basins (Del Ben and Guarnieri 2000). Their age is tentatively inferred as Pliocene to Pleistocene (Fig. 3).

Over the shelf and the upper slope, the Plio-Pleistocene deposits consist of clastic and terrigenous deposits whereas in the basinal areas, hemipelagites, locally intercalated with volcanoclastic sediments, are common (Bacini Sedimentari 1980). The Quaternary deposits of the shelf are subdivided into subunits of variable thicknesses and internal geometries which are delimited by unconformities. Their origin is related to sea-level changes (Agate et al. 1993; Catalano et al. 1998).

\section{Materials and methods}

An innovative, high-energy power supply system was used for the generation of the electrical pulse in the sparker arrays. The system consists of a low- to highvoltage converter (from 100-380 to 3,500 V), a number of capacitors, and an electrical trigger system. All components are solid state, and eliminate the need for a spark-gap or mechanical switching. The energy stored in the capacitors can thus be transferred to the sparker arrays in an extremely short time (typically $<0.5 \mathrm{~ms}$ ). This allows the maintenance of a constant source pulse over the entire power output range from 0.3 to $10 \mathrm{~kJ}$

A conventional three-tip sparker array, and sparker arrays with eight (also a conventional sparker array), 400 and 600 tips were available onboard.

A single-channel streamer with an active section of $2.8 \mathrm{~m}$, containing seven high-resolution hydrophones, was used for the single-channel acquisition. For the multi-channel acquisition, a 24-channel streamer, consisting of $300 \mathrm{~m}$ of active section, was used. The group interval was $12.5 \mathrm{~m}$, with a shot interval of $12.5 \mathrm{~m}$ which resulted in a 12-fold coverage.

The Delph seismic recording system was used for the acquisition of single-channel profiles, whereas the Geode and Seismic Treatment Method (STM) 96 (Pepe 1996) systems were adopted for the multi-channel data. The Delph seismic and STM 96 software was used for the processing of single-channel data. The Sioseis software, which is a non-commercial software package for enhancing and manipulating marine seismic reflection and refraction data, was used for the processing of the multi-channel data.

Production recording was started by selecting a sampling rate of $6 \mathrm{kHz}$ and a record length of $1.5 \mathrm{~s}$ two-way travel time (t.w.t.t.) for the acquisition of the single-channel data. The multi-channel systems acquired 24 channels of data with a $4-\mathrm{kHz}$ sampling rate and a record length of $2.5 \mathrm{~s}$ (t.w.t.t.). Production was carried out for 9 days. This effort resulted in more than $900 \mathrm{~km}$ of seismic lines covering much of the CNS (Fig. 4).

Multi-channel seismic data processing was performed by running the following routines: edit of the data, geometry, velocity analysis, normal move out, stack of the common depth point reflection, trace mixing, time variant filters, time variant gain, and spherical divergence correction. Only the last four routines were applied to the single-channel seismic data.

Signal penetration was found to exceed $400 \mathrm{~ms}$ (t.w.t.t.) in the single-channel lines, and more than $900 \mathrm{~ms}$ (t.w.t.t.) in the multi-channel profiles. The vertical resolution is up to $2.5 \mathrm{~m}$ near the seafloor.

\section{Deployment procedure}

The first step of the seismic survey was to test the differences in the acoustic pulses generated by the sparker arrays available onboard. For this, we used the $4.5-\mathrm{kJ}$ power supply at a regular trigger interval of $4 \mathrm{~s}$, the Delph seismic acquisition system, and a single-channel streamer located $\sim 10 \mathrm{~m}$ behind the sparker array, itself $\sim 15 \mathrm{~m}$ behind the ship's stern. Analog anti-aliasing filters with cut-off frequencies of 2,400 and $800 \mathrm{~Hz}$, and $48 \mathrm{~dB}$ of attenuation were used. The sampling rate was set initially to $6 \mathrm{kHz}$, and then gradually reduced to $2 \mathrm{kHz}$.

Spectral analysis was applied to both the direct and reflected arrivals for a number of traces, all shot with the same sparker array, over a range of 128 to 512 samples. The results indicate that (1) there is no difference in the acoustic pulses between different shots, and (2) there is a 
Fig. 4 Location map of seismic profiles acquired during cruise Sicily 2001. Details are shown at smaller scales in boxes $\mathbf{A}$ and B. Water depth contours are in metres
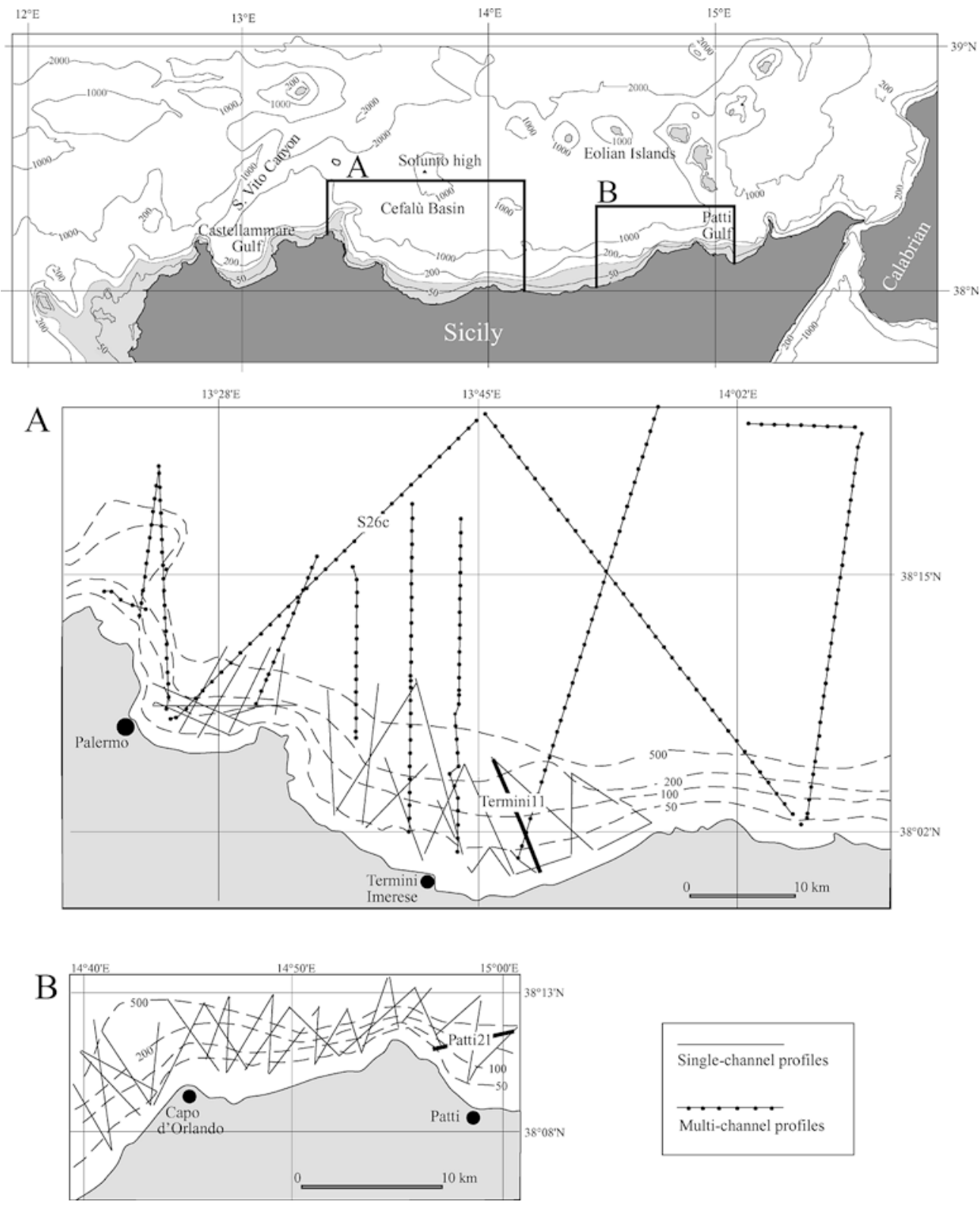

Single-channel profiles

Multi-channel profiles significant difference in the physical properties of acoustic pulses generated by conventional three- or eighttip sparker arrays, and those with 400 or 600 tips. The comparison of the amplitude spectra computed for the signal generated by the sparker arrays with three and 400 tips indicates that both are characterised by the same quality factor $(\mathrm{Q} \sim 1)$. However, the signal generated by the sparker array with 400 tips has the following advantages: (1) it has a much more impulsive characteristic; (2) the base frequency at $600 \mathrm{~Hz}$, as opposed to the $150-200 \mathrm{~Hz}$ for the three-tip sparker array, is much higher; (3) it lacks multiple waves, resulting in the absence of ghost traces; and (4) the effective energy is up to 4 times higher (Fig. 5).

A positive relationship exists between the time needed to release the energy in the capacitors at different charge levels. An energy output of 4.5 and $8 \mathrm{~kJ}$, over 400 and 600 tips respectively, provides the optimal signal.

\section{Results}

Examples of the acquired, processed, and interpreted seismic lines are presented below. Seismo-stratigraphic analysis tools and methods were used to define seismic units, infer their lithologies, subdivide the Plio-Pleistocene sedimentary succession into depositional sequences and systems tracts, and to identify older deposits. In the absence of wells in the investigated area, we use data obtained from dredge samples recovered on structural highs (Bacini Sedimentari 1980; D'Argenio 1999) to infer their age, and to make correlations with Plio-Pleistocene 
Fig. 5A, B Seismic profile and amplitude spectra of the direct arrivals generated by sparker arrays with three (A) and 600 (B) tips. Sampling rate has been set at 2 and $6 \mathrm{kHz}$ respectively. The number of the samples is 256 and 512 respectively
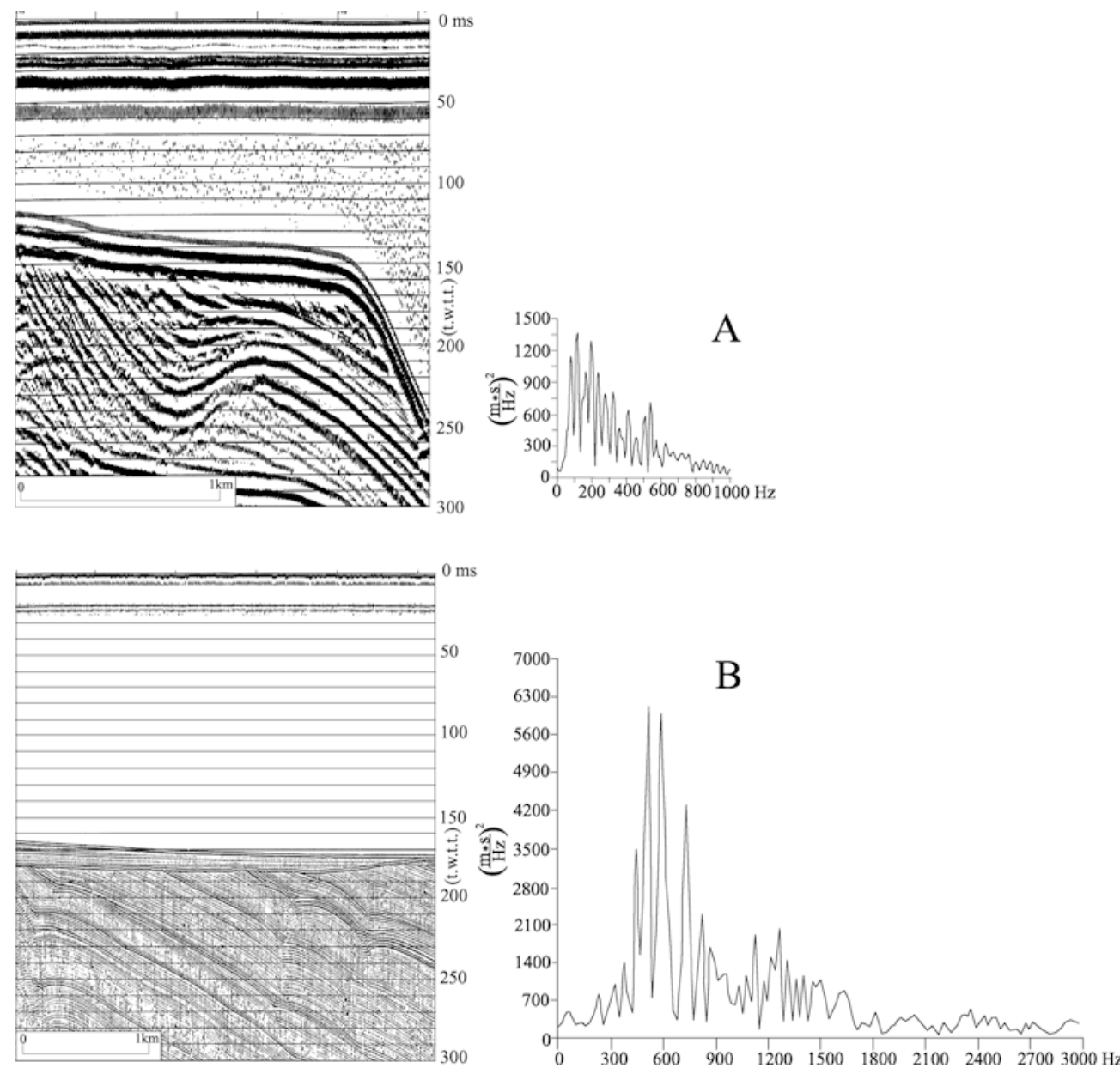

sedimentary successions (Catalano et al. 1998) outcropping close to the investigated area.

\section{Single-channel profile Termini 11}

The seismic line Termini 11 runs in a SE-NW direction through the Termini Imerese Gulf (Fig. 6). Nine seismic units (namely A1, A2, A3, B, C, D, D1, E, F), with variable geometries and seismic facies, were identified. The oldest (unit F) is characterised by a chaotic to reflection-free seismic signature, being limited upwards by an erosional truncation. It is recognised in the nearshore sector of the shelf only.

Seismic unit E shows a succession of low-amplitude reflectors of good lateral continuity, dipping seawards between 5 and $6^{\circ}$ parallel to divergent internal geometry, with onlap reflectors terminating on top of unit F. Two erosional truncations are recognised: landward-dipping normal faults, and local offset reflectors. The top of unit $\mathrm{E}$ is defined by a change in seismic characters.

Seismic unit D shows a rhythmic succession of highand low-amplitude reflectors, dipping seawards between 5 and $6^{\circ}$. On the outer shelf, the dip of the reflectors flattens slightly at a depth of 0.45 s t.w.t.t. A systematic pattern of buried gullies is observed within this unit. Most of these are evenly spaced and a few metres deep, locally truncating individual reflectors. Northwards, reflectors are locally offset by high-angle normal faults. Seawards, a wedge-shaped small-scale unit (D1), characterised by oblique-tangential prograding reflectors, is recognised.

Seismic unit $\mathrm{C}$ is characterised by high-frequency, low-amplitude reflectors with an oblique pattern and wedge-shaped geometry. Seismic reflectors downlap on top of unit D. Seismic unit B has a sheet-like geometry, parallel configuration, and low-amplitude reflectors with onlap terminations on top of unit C. Units E, D, D1, C and $\mathrm{B}$ are terminated upwards by an erosional truncation (U).

Seismic unit A3 is located along the shelf margin. It is wedge-shaped and shows high-frequency, oblique-tangential prograding reflectors downlapping on top of unit B. Seismic units A2 and A1 exhibit a slightly prograding, wedge-shaped geometry with well-defined and laterally continuous reflectors. Seawards, the reflectors downlap on the erosional surface U. Unit A1 reveals a base-discordant seismic reflection pattern, with onlap reflectors terminating on unit A2. Weak mass-failure processes locally deform the reflectors. Landwards, 
SE
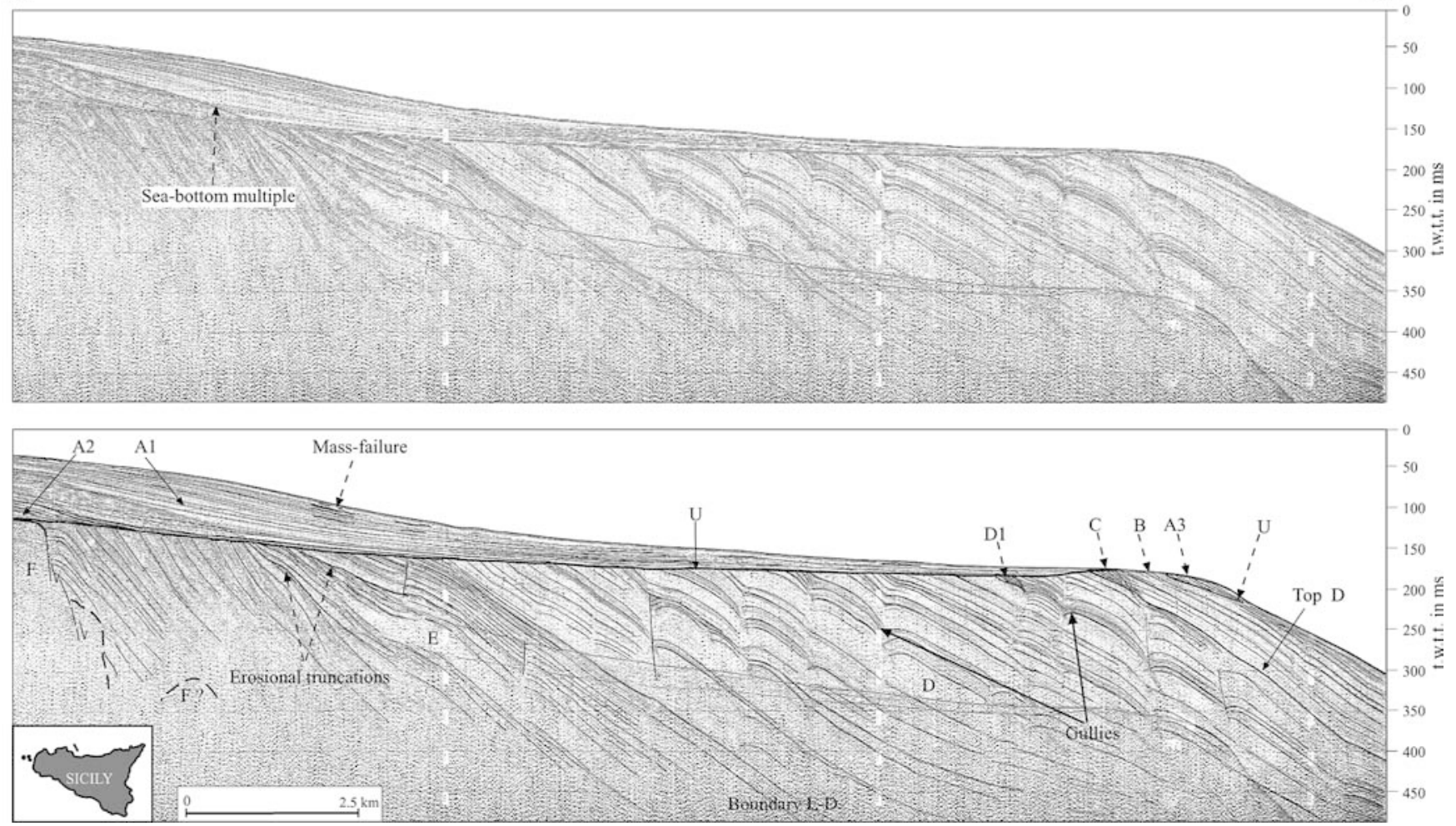

Fig. 6 Single-channel seismic profile Termini 11 (top), and interpretative line-drawing (bottom). Detailed location in Fig. 5

units $\mathrm{A} 2$ and $\mathrm{A} 1$ reach thicknesses of $60 \mathrm{~m}$ when using an average seismic velocity of $1,650 \mathrm{~m} / \mathrm{s}$.

The top of unit $\mathrm{F}$ is interpreted as being representative of the regional unconformity which, on the northern Sicilian mainland, corresponds to the base of the Pleistocene (Montanari 1966; Ruggeri 1978; Fois 1990). On land, the deposits underlying the Pleistocene consist of tectonically deformed Mesozoic to early Pliocene carbonate and terrigenous rocks.

Seismic units E-A3 are interpreted to have formed during the (?) Pleistocene. Their internal architecture was mainly controlled by high-frequency and highamplitude sea-level changes. The erosional unconformity " $U$ " is interpreted as having formed during the last sea-level fall when the sea stood $\sim 110 \mathrm{~m}$ below the present level between 85,000 and 18,000-14,000 years ago (Williams et al. 1988). The progradational pattern of seismic unit A3 suggests that it is composed by coastal clastic sediments deposited during the lowstand stage of the last sea-level change (18,000-14,000 a B.P.). A shelfwide, transgressive marine erosional surface formed during the subsequent sea-level rise. It merges with the previously developed sub-aerial unconformity "U". The units $\mathrm{A} 2$ and $\mathrm{A} 1$ have successively been formed during the transgressive $(14,000-6,000$ a B.P.) and highstand $(6,000-0$ a в.P.) stages. On the whole, seismic units A1, $\mathrm{A} 2$ and $\mathrm{A} 3$ pertain to the Late Quaternary depositional sequence (LQDS) corresponding to the last eustatic cycle (Fig. 7).
The formation of gullies could be associated with the following processes: (1) channel incision during sea-level lowstand; the channel is later successively filled and overlain by late lowstand and transgressive deposits; (2) erosion as a consequence of gravity-driven mass movement; and (3) listric growth faults.

\section{Single-channel profile Patti 21}

The seismic line Patti 21 runs in a WSW-ENE direction across the shelf and the upper slope of the Patti Gulf sector (Fig. 8). Two sectors, separated by a major slope break at $\sim 95 \mathrm{~m}$, have been distinguished on the shelf. The seafloor morphology of the inner shelf is rough and relatively steep. Seawards, the seafloor dips gently and is bordered by a deep shelf break at $\sim 130 \mathrm{~m}$. A number of erosional channels are observed on the upper slope.

Five seismic units (namely CR, L, M, A3 and A12), with variable geometry and seismic facies, have been identified. The lower one (unit CR) is characterised by chaotic to reflection-free seismic facies. Upwards, it is limited by a high-amplitude and discontinuous seismic reflector which corresponds to an erosional surface (U) marked by wave-cut terraces separated by little escarpments. A number of normal faults offset this reflector.

Seismic unit L is characterised by rhythmic successions of high- and low-amplitude reflectors and is limited upwards by two high-amplitude and well-defined continuous reflectors. In the lower part of this unit, the reflectors have a wavy geometry. Unit M is characterised 


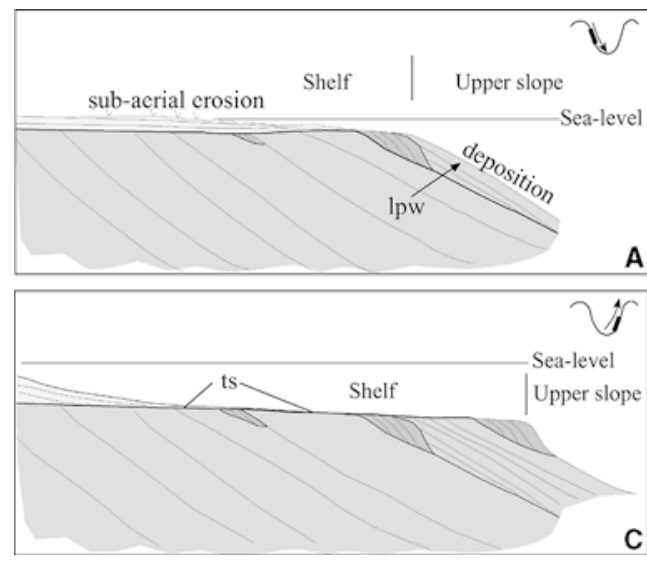

Fig. 7A-D Schematic diagrams illustrating successive stages of the depositional sequence development in the Termini Imerese Gulf: (A) sediment is deposited (onlapping fill) on the upper slope during sea-level fall $(l p w)$, while sub-aerial erosion scours the inner shelf; (B) maximum sea-level lowstand leaves a progradational sedimentary wedge ( $p s w$ ) along the shelf margin; (C) during the subsequent sea-level rise, marine erosion results in planation of the shelf to produce a transgressive surface $(t s)$. A transgressive wedge $(t w)$ is formed on the shelf; (D) a minor relative sea-level-fall results in a downward shift of the transgressive onlap terminations. A thick highstand aggradational/progradational wedge (apw) subsequently develops. Not to scale

by well-stratified, high-frequency reflectors. This unit unconformably overlies older deposits. An erosional surface (U) truncates unit $\mathrm{M}$ at the top. Furthermore, an erosional to depositional channel-fill, up to $100 \mathrm{~ms}$ (t.w.t.t.) thick, is incorporated into unit M. Seismic unit A3 is $\sim 30 \mathrm{~ms}$ (t.w.t.t.) thick, has a wedge-shaped geometry, and displays prograding low-amplitude reflectors which downlap onto unit M. It is situated at the shelf edge, and lies above the erosional surface U. Seismic unit A $1-2$ is $<30 \mathrm{~ms}$ (t.w.t.t.) thick and characterised by wellstratified reflectors. It unconformably overlies both units $\mathrm{CR}$ and $\mathrm{M}$.

We attribute the seismic unit $\mathrm{CR}$ to the crystalline rocks of the Calabro-Peloritani province. In seismic unit L, the wavy geometry of the reflectors suggests synsedimentary compressive deformation. Compressive deformation also slightly deformed unit M. Normal faults offset the reflectors of units CR, L and $\mathrm{M}$ and are responsible for the present-day physiographic setting of this area.

Units A3 and A1-2 represent the lowstand and the transgressive-highstand systems tracts of the Late Quaternary depositional sequence respectively. The formation of the erosional channels is interpreted to be strictly related to the sea-level lowstand.

The multi-channel seismic line S26C

Seismic line S26C runs in a SW-NE direction from the Palermo Gulf along the Cefalù Basin to the Solunto high. Two segments crossing the shelf and the Cefalù Basin are shown and discussed below.

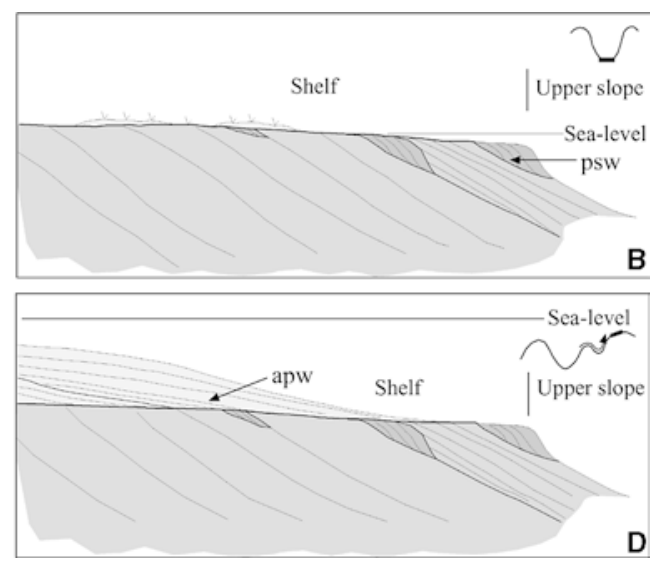

The shelf

A high-amplitude reflector overlying a transparent horizon (seismic unit MC) is located between $\sim 200$ and $\sim 500$ ms (t.w.t.t.) in the lowest part of the line (Fig. 9). The transparent body is unconformably overlain by seismic unit $F$ which is variable in thickness and acoustic reflectivity. Low-amplitude reflectors characterise the lowest part, whereas the upper part shows a rhythmic succession of low- and high-amplitude reflectors with very good lateral continuity. Onlap reflector terminations are observed in the upper part of unit F. Landwards, the upper part of unit $F$ is truncated by an erosional surface (U). Lens-shaped reflectors are observed in sectors where the top of the transparent body changes rapidly in depth. A failure scar is visible on the upper slope.

We associate seismic facies MC with the MesozoicCenozoic carbonate deposits. Its top could represent an erosional surface. Unit $\mathrm{F}$ is tentatively attributed to the Plio-Pleistocene deposits. The erosional surface U is interpreted to have formed during the last sea-level fall.

Seawards, late Miocene (?)-early Pliocene northdipping, high-angle reverse faults structure unit MC, producing an antiformal stack. Reverse faults also affected the lower part of unit F. Later, normal faults partly dissected the back- and forelimb of the structural high. The depth of the Mesozoic-Cenozoic sedimentary body and sea-level changes mainly control the thickness and the geometry of unit F.

\section{The Cefalù Basin}

At the landward site, an anomalous body (seismic facies $\mathrm{AB}$ ), more than $\sim 0.5 \mathrm{~s}$ (t.w.t.t.) thick and characterised by a transparent seismic facies, is limited at its top by a low-amplitude reflector (Fig. 10). Here, too, three seismic units (SR1, SR2 and PR) can be identified. The lowest one (unit SR1) is characterised by lowamplitude reflectors with well-defined lateral continuity. A high-amplitude and well-defined, laterally continuous reflector defines its top. Reflectors clearly diverge towards the normal fault bordering the basin to the south. 
Fig. 8 Single-channel seismic profile Patti 21 (top), and interpretative line-drawing (bottom). Detailed location in Fig. 5
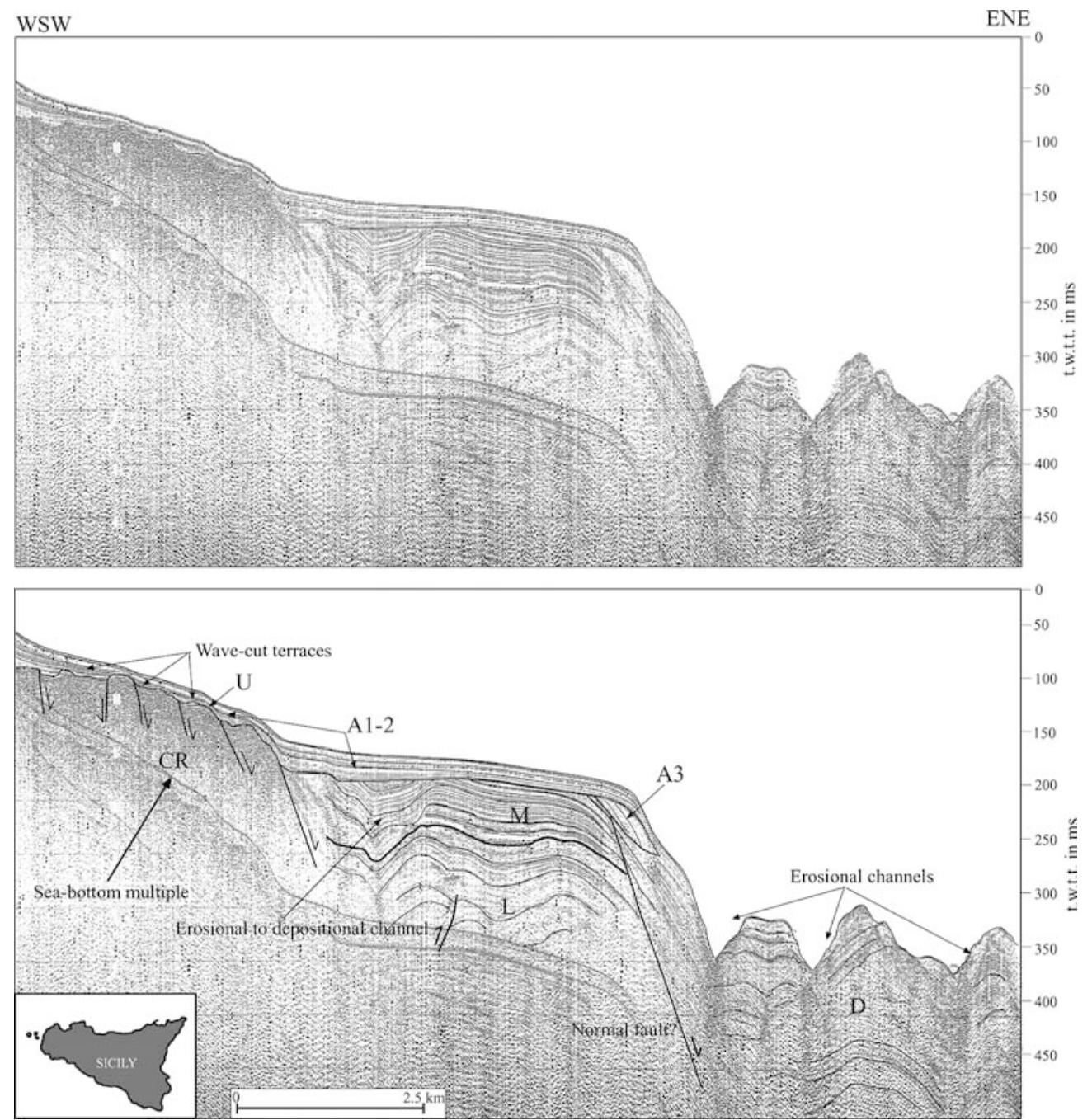

A number of small-scale, seaward-dipping normal faults offset the seismic reflectors at different levels.

Seismic unit SR2 shows a rhythmic succession of lowand high-amplitude reflectors with well-defined lateral continuity. Onlap reflector terminations are recognised in the central sector of the basin. Two $\sim 40 \mathrm{~ms}$ (t.w.t.t.) thick, tabular-shaped bodies (TU), which are seismically transparent, characterise the upper part of this unit.

A well-stratified sedimentary package (PR), which drapes and smoothens underlying features, is located on top of unit SR2. Two subunits can be identified within this unit. The lower one shows very low-amplitude reflectors, whereas the upper one shows a rhythmic succession of low- and high-amplitude reflectors of variable lateral continuity. The geometry of the reflectors is of the onlap filling-type.

We correlate unit $\mathrm{AB}$ with the upper part of the Mesozoic-Cenozoic deposits. Alternatively, this body could be a diapiric structure, which are widespread in other parts of the Cefalù Basin (Fabbri and Curzi 1979). Seismic reflectors of units SR1 and SR2 clearly diverge towards the normal fault bordering the Cefalù Basin to the south, demonstrating syn-extensional deposition.
Seismic unit SR2 shows the character both of hemipelagic sedimentation and of a terrigenous turbidite. On the whole, units SR1 and SR2 could be correlated to the (?) Middle-Upper Pliocene syn-extensional deposits previously documented towards the east (Pepe et al. 2000 and references therein).

The seismic signature suggests that unit PR is a response to both hemipelagic sedimentation and smallscale mass-failure deposition. The horizontal pattern of the seismic reflectors demonstrates post-extensional deposition.

The "TU" bodies are interpreted as mass-failure deposits because of their general appearance and their position at the foot of the continental slope. The external sector of the intra-slope basin developed north of the Palermo Gulf could be one of the source areas for these deposits (see Fig. 9).

\section{Discussion and conclusions}

Ghosting is among the most common causes of degrading data quality and results in a loss of vertical 
Fig. 9 Segment of the multichannel seismic line S26C which crosses the continental platform and the upper slope offshore Palermo (top), together with an interpretative line-drawing (bottom). Detailed location in Fig. 5
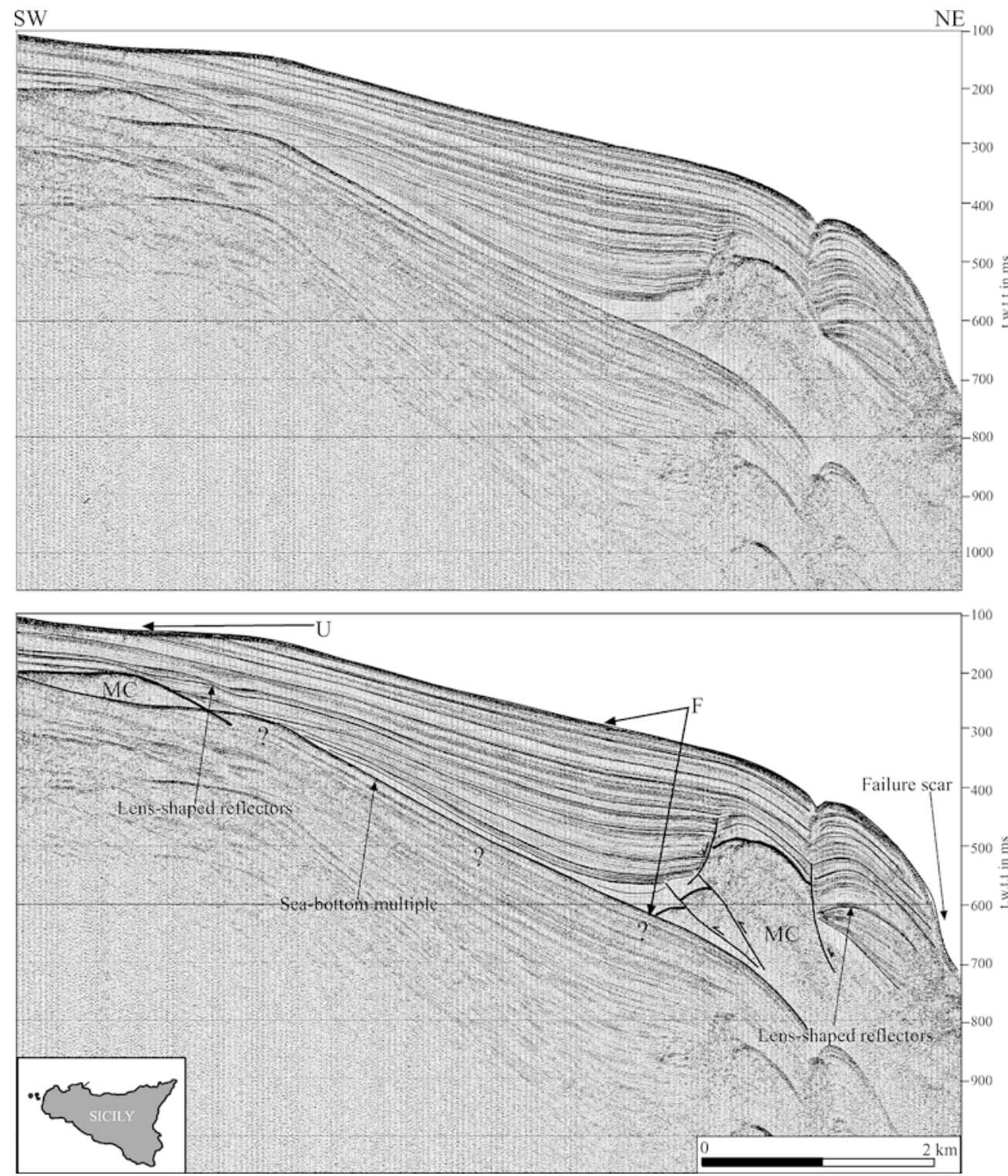

resolution, even at shallow water depth. A pure, nonoscillating acoustic pulse, which resulted in the absence of ghosting in the seismic signature, has been produced with a multi-electrode sparker array, and selecting an energy output of $\sim 10 \mathrm{~J}$ per tip. Due to the absence of ghosting, we obtain, for the first time, seismic profiles with a resolution and penetration adequate for the description of the geometries and seismic facies of depositional sequences and systems tracts forming on the shelf of the CNS, as well as some fine details of the Plio-Pleistocene sedimentary infill of deep basins developed north of this area. Major new results can be summarised as follows.

In the upper part of the continental slope off Palermo, a similar structural pattern can be recognised as that which has recently been documented in the adjacent Termini Basin (Fig. 3; Catalano et al. 2002). Towards the north, i.e. in the Cefalù Basin, it has been proven that (?) Middle-Upper Pliocene reflectors (SR1 and SR2 in Fig. 10) clearly diverge towards the normal fault bordering the basin, thereby demonstrating synextensional deposition. The data are in agreement with other studies which cover large sectors of the Cefalù Basin (Bacini Sedimentari 1980; Fabbri et al. 1981; Barone et al. 1982; Pepe et al. 2000). Thus, we propose that two types of basins formed in the central sector of the CNS: (1) minor intra-slope basins (e.g. Palermo and Termini basins) whose origin is related to the (?) late Miocene-early Pliocene shortening and thrusting of the SMC, and (2) major extensional basins (e.g. Cefalù Basin) whose origin is connected to the continental rifting which affected the internal side of the SMC during the middle (?)-late Pliocene.

It is well accepted that the continental margins formed in the Tyrrhenian Sea, i.e. the east Sardinia margin (Spadini et al. 1995), undergoing differential 

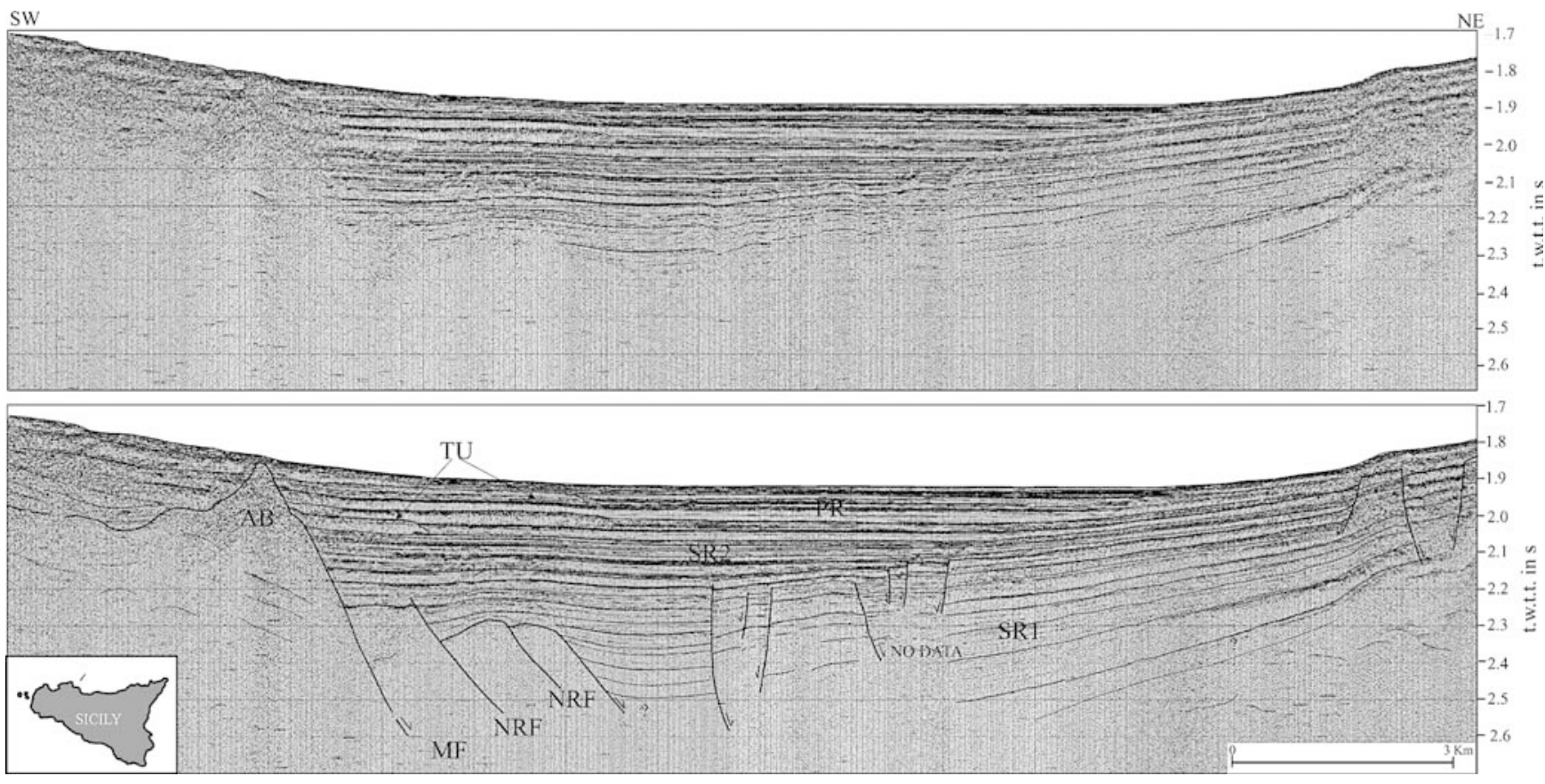

Fig. 10 Segment of the multi-channel seismic line S26C which crosses the Cefalù Basin (top), together with an interpretative linedrawing (bottom). MF Master fault, NRF normal fault reactivated as reverse fault. Detailed location in Fig. 5

uplift and subsidence during Neogene to Recent times. An uplift of the northern Sicily shelf and surrounding areas during the Pleistocene is testified by (1) the Pleistocene coastal deposits occurring in the western sector of the CNS which show a regressive trend (Mauz et al. 1997; Arces et al. 2000), and (2) the Pleistocene deposits outcropping close to the study area and which are uplifted tens of metres (Hugonie 1982). Moreover, an uplift of the southern sector of the margin, as a consequence of thermal perturbation due to the thinning of the lithosphere which is not compensated by local isostasy, is predicted by forward modelling, thus constraining the late Neogene to Recent tectonic and stratigraphic evolution of the CNS (Pepe, unpublished data). Therefore, it is evident that along the CNS eustatic and tectonic processes combine to cause both relatively short- and long-term sea-level changes which control the space available for sediments.

Our data, in agreement with other studies, indicate that a number of depositional sequences formed on the northern Sicily shelf from the early (?) Pleistocene to the Holocene. However, in the Termini Imerese Gulf we observe that (1) the transgressive deposits are preserved in the last sequence; (2) the last two sequences also include remnant parts of the lowstand deposits (units D1 and C in Fig. 6); and (3) the preservation of the oldest sequences is limited mainly to the highstand and falling systems tracts (units E-D in Fig. 6). This pattern is observed in another part of the CNS, too, i.e. in the Castellammare Basin (Agate and Lucido 1995). We conclude that, although on the northern Sicily shelf short-term fluctuations in sea level play an important role for the formation of a number of depositional sequences during the Pleistocene, uplift of this area is one of the most important causes for the systematic non-preservation of the lowstand and transgressive deposits in the oldest sequences.

Acknowledgements We thank Giovanni Bertotti, Massimiliano Barchi, and Maria Stella Giammarinaro for useful discussion and reviewing an earlier version of this paper. Giovanni de Alteriis and an anonymous reviewer provided thoughtful comments on the manuscript. This research has been funded by a MIUR program (Cofin 2002-2003) grant to R. Catalano.

\section{References}

Agate M, Lucido M (1995) Caratteri morfologici e sismostratigrafici della piattaforma continentale della Sicilia nord-occidentale. Naturalista Sicil 19:3-25

Agate M, Catalano R, Infuso S, Lucido M, Mirabile L, Sulli A (1993) Structural evolution of the Northern Sicily continental margin during the Plio-Pleistocene. In: Max MD, Colantoni P (eds) Geological development of the Sicilian-Tunisian Platform. Unesco Rep Mar Sci 58:25-30

Agate M, D’Argenio A, Di Maio D, Lo Iacono C, Lucido M, Mancuso M, Scannavino M (1998) La dinamica sedimentaria dell'offshore della Sicilia nord-occidentale durante il tardo Quaternario. In: Catalano R, Lo Cicero G (eds) Guida Escursioni 79 Congr Naz SGI La Sicilia Occidentale 1:157-167

Arces M, Aversa S, Lo Cicero G, Nocilla N (2000) The Pleistocene "Calcareniti di Marsala": geotechnical and sedimentological characterisation. Mem Soc Geol It 55:483-489

Bacini Sedimentari (1980) Dati geologici preliminari sul bacino di Cefalù (Mar Tirreno). Ateneo Parmense Acta Nat16:3-18

Barberi F, Innocenti F, Ferrara G, Keller J, Villari L (1974) Evolution of Aeolian Arc (Southern Tyrrhenian Sea). Earth Planet Sci Lett 22:123-132

Barone A, Fabbri A, Rossi S, Sartori R (1982) Geological structure and evolution of the marine areas adjacent to the Calabrian arc. Earth Evol Sci 3:207-221 
Beccaluva L, Morlotti E, Torelli L (1986) Notes on the geology of the Elimi Chain area (south-western margin of the Tyrrhenian Sea). Mem Soc Geol It 27:213-232

Bigi G, Cosentino D, Parotto M, Sartori R, Scandone P (eds) (1983) Structural model of Italy, scale 1:500,000. Cons Naz Ric, Rome

Catalano R, D'Argenio B, Montanari L, Morlotti E, Torelli L (1985) Marine geology of the NW Sicily offshore (Sardinia Channel) and its relationships with mainland structures. Boll Soc Geol It 104:207-215

Catalano R, Di Stefano P, Sulli A, Vitale PF (1996) Paleogeography and structure of the Central Mediterranean: Sicily and its offshore area. Tectonophysics 260:291-323

Catalano R, Di Stefano E, Sulli A, Vitale PF, Infuso S, Vail PR (1998) Sequences and systems tracts calibrated by high-resolution bio-chronostratigraphy: the central Mediterranean PlioPleistocene record. SEPM Spec Publ 60:115-177

Catalano R, Doglioni C, Merlini S, Sulli A (2002) The subduction of the Ionian crust and the outer Calabrian accretionary wedge. EAGE Worksh Geodynamics of the Mediterranean and Impact on Hydrocarbon Exploration, 27-30 May, Florence, Italy

D’Argenio A (1999) Analisi stratigrafica delle successioni mesozoiche e terziarie dell'offshore della Sicilia nord occidentale. Naturalista Sicil 23:43-61

Del Ben A, Guarnieri P (2000) Neogene transgression in the Cefalù Basin (southern Tyrrhenian): comparison between land and marine data. Mem Soc Geol It 55:27-33

Fabbri A, Curzi P (1979) The Messinian of the Tyrrhenian Sea: seismic evidences and dynamic implications. Giornale Geol 53:215-248

Fabbri A, Gallignani P, Zitellini N (1981) Geological evolution of the peri-Tyrrhenian sedimentary basins. In: Wezel FC (ed) Sedimentary basins of Mediterranean margins. Tecnoprint, Bologna, pp 101-126

Fois E (1990) Stratigraphy and palaeogeography of the Capo Milazzo area (NE Sicily, Italy): clues to the evolution of the southern margin of the Tyrrhenian Basin during the Neogene. Palaeogeogr Palaeoclimatol Palaeoecol 78:87-108
Hugonie MG (1982) Mouvements tectoniques et variations de la morphogenèse au Quaternaire en Sicile septentrionale. Rev Geogr Phys Dyn 23:3-14

Lucido M (1992) Geomorfologia della piattaforma continentale tra Torre del Pozzillo e Torre Mondello (Sicilia nord-occidentale). Naturalista Sicil 16(1/2):91-107

Mauz B, Buccheri G, Zoller L, Greco A (1997) Middle to Upper Pleistocene morphostructural evolution of NW Sicily coast: thermoluminescence dating and paleontological-stratigraphical evaluations of littoral deposits. Palaeogeogr Palaeoclimatol Palaeoecol 128:269-285

Montanari L (1966) Geologia dei monti di Trabia (Sicilia). Riv Miner Sicil 97/99:35-81

Nigro F, Sulli A (1995) Plio-Pleistocene extensional tectonics in the western Peloritani area and its offshore (northeastern Sicily). Tectonophysics 252:295-305

Pepe F (1996) S.T.M.96: un sistema finalizzato all'acquisizione multicanale ed all'elaborazione di segnali sismici ad alta risoluzione. Atti 15 Conv GNGTS Cons Naz Ric, Rome, pp 299-303

Pepe F, Bertotti G, Cella F, Marsella E (2000) Rifted margin formation in the South Tyrrhenian Sea: a high-resolution seismic profile across the North Sicily passive continental margin. Tectonics 19:241-257

Ruggeri G (1978) Una trasgressione del Pleistocene inf. nella Sicilia occidentale. Naturalista Sicil 2:159-171

Spadini G, Bertotti G, Cloething S (1995) Tectono-stratigraphic modelling of the Sardinian margin of the Tyrrhenian Sea. Tectonophysics 252:269-284

Wezel FC, Savelli D, Bellagamba M, Tramontana M, Bartole R (1981) Plio-Quaternary depositional style of sedimentary basins along insular Tyrrhenian margins. In: Wezel FC (ed) Sedimentary basins of Mediterranean margins. Tecnoprint, Bologna, pp 239-269

Williams DF, Thunnel RC, Tappa E, Rio D, Raffi I (1988) Chronology of the Pleistocene oxygen isotope record, 0-1.88 M.yr B.P. Palaeogeogr Palaeoclimatol Palaeoecol $61: 221-240$ 